\title{
Analisis Software Robot Sterilisasi Ruangan Menggunakan Kendali Maze Solving
}

Analysis of Robot Room Sterilization Software Using Maze Solving Control

\author{
Bimantyoso Hamdikatama*1, Arif Setyanto ${ }^{2}$, Ferry Wahyu Wibowo ${ }^{3}$ \\ ${ }^{1,2,3}$ Magister Teknik Informatika; Universitas Amikom Yogyakarta \\ 1, 2, 3 Yogyakarta, Indonesia \\ e-mail:*1bimantyoso.h@students.amikom.ac.id, ${ }^{2}$ arief s@@amikom.ac.id, \\ ferry.w.wibowo@ieee.org
}

\begin{abstract}
Abstrak - Ruangan ibadah berjamaah adalah tempat yang sering digunakan banyak orang secara bersamaan dan menjadi tempat potensial guna penyebaran Corona.Virus yang di bawa oleh orang terinfeksi dapat menempel pada lantai, tembok kursi dan isi ruangan sehingga terhirup oleh jamaah saat melakukan ibadah, sehingga diperlukan alat guna membantu mensterilkan ruangan ibadah secara efisien. Dengan robot yang dilengkapi dengan sinar UVC diharapkan dapat membantu proses sterilisiasi secara efektif. Tujuan penelitian ini adalah guna menganalisa kinerja sistem robot sterilisasi dengan kendali Maze Solving, guna dapat bekerja dengan gerak lurus dan berputar. Pembaruan pada penelitian ini adalah penerapan kendali menggunakan algoritma Maze Solving pada robot sterilisasi ruangan. Penelitian ini dilakukan dengan tahap analisa, pengkodean, dan uji coba. Algoritma Maze Solving dengan KP=10, Ki=0 dan Kd=120 dengan kombinasi tambahan rotary encoder, sensor kompas dan sensor jarak. Hasil uji memperlihatkan peningkatan kerja robot dengan nilai standart deviasi tertinggi guna poin kelurusan gerak 10,48 menjadi 0,34 ketepatan jarak tempuh dari 10,4 menjadi 0,42 . Waktu yang dibutuhkan robot sterilisasi pada ruangan $10 \mathrm{~m} \times 10 \mathrm{~m}$ adalah 54,5 menit dan pembacaan halangan rintang dengan sensor jarak akurat dibawah $60 \mathrm{~cm}$.
\end{abstract}

Kata kunci-komponen ; Covid19; Maze Solving; Robot; Sterilisasi Ruangan;

\begin{abstract}
The congregational prayer room is a place that is often used by many people simultaneously and is a potential place for the spread of Corona. Viruses carried by infected people can stick to the floor, walls of chairs and the contents of the room so that it is inhaled by the congregation during worship, so a tool is needed. to help sterilize places of worship efficiently. With a robot equipped with UVC light, it is hoped that it can help the sterilization process effectively. The purpose of this research is to analyze the performance of the sterilization robot system with Maze Solving control, to be able to work with a straight and rotating motion. The update in this study is the application of control using the Maze Solving algorithm in a room sterilization robot. This research was conducted by analyzing, coding, and testing stages. Maze Solving algorithm with KP = $10, K i=0$ and $K d=120$ with an additional combination of rotary encoder, compass sensor and proximity sensor. The test results showed an increase in the work of the robot with the highest standard deviation value for motion straightness points 10.48 to 0.34 , the distance accuracy from 10.4 to 0.42 . The time required for the sterilization robot in a room of $10 \mathrm{~m} \times 10 \mathrm{~m}$ is 54,5 minutes and the reading of obstacles with an accurate distance sensor is below $60 \mathrm{~cm}$.
\end{abstract}

Keywords - Component ; Covid19; Maze Solving; Robot; Room Sterilization 


\section{PENDAHULUAN}

Covid-19 adalah penyakit menular yang disebabkan oleh sindrom pernapasan akut corona virus 2 (Sars-CoV-2)[1]. Infeksi virus Corona disebut COVID-19 (Corona Virus Disease 2019) pertama kali ditemukan di kota Wuhan, China pada akhir Desember 2019. Wabah penyakit ini sangat mengguncang masyarakat dunia, mengingat hampir 200 Negara di Dunia terjangkit oleh virus ini termasuk Indonesia.

Upaya dilakukan sebagai pencegahan penyebaran virus, khususnya dalam kegiatan ibadah. Pada kegiatan ibadah sering dilakukan secara berjamaah sehingga ruangan yang dipakai menjadi potensial tersebarnya virus. Penyebaran Covid-19 ini dapat melalui benda sekitar [3]. Para jamaah yang positif mengidap covid-19 dapat menyebarkan virus pada lantai dan benda di ruangan dan berpotensi menularkan pada orang lain.

Penyemprotan Desinfektan dirasa tidak efektif sehingga dibutuhkan alat guna sterilisasi otomatis secara berkala. Inilah alasan hadirnya robot sterilisasi ruangan yang memanfaatkan sinar UVC yang dilengkapi microcontroller yang dapat dikendalikan secara otomatis atau manual. Sinar UVC adalah sinar dengan panjang gelombang $254 \mathrm{~nm}$ yang memiliki sifat germicidal yang dapat membunuh virus, kuman dan bakteri [5].

Pengunaan sinar UVC perlu berhati-hati karena sinar UVC tidak boleh terpapar langsung ke manusia [6]. Penelitian sebelumnya oleh dokter Anthony Griffiths, menunjukan sinar UVC dapat menonaktifkan 99\% virus Corona dengan dosis $5 \mathrm{~mJ} / \mathrm{cm} 2$ dalam waktu 6 detik [7]. guna dapat mencapai nilai germicidal minimum yang dapat membunuh virus Corona setiap bagian ruangan harus terpapar sinar UVC dengan dosis dan lama waktu penyinaran yang tepat [5].

Penelitian ini bertujuan guna menganalisis peningkatan kinerja sistem kendali robot sterilisasi ruangan dengan menerapkan Algoritma Maze Solving menggantikan sistem kendali konvensional set-timer. Kebaruan penelitian ini adalah penerapan Algoitma Maze Solving guna sistem kendali robot sterilisasi ruangan, Alasan menggunakan Algoritma Maze Solving yang memiliki ukuran memanjang 60 $\mathrm{cm}$ dengan 2 roda penggerak. Ukuran robot yang tidak pendek ini membuat robot sulit dikendalikan, sehingga penerapan Algoritma
Maze Solving dibutuhkan agar robot dapat bergerak dan berputar secara tepat, Jika dibandingkan dengan Algoritma PID (Propotional - Integral - Derivative) telah banyak dilakukan oleh peneliti lain sehingga pada penelitian ini akan dicoba seberapa efektif penggunaan Algoritma Maze Solving dalam sistem kendali robot beroda dan juga agar tidak ada bagian ruangan yang terlewat. Pengujian dilakukan pada fungsi aplikasi robot, dilanjutkan dengan pengujian kendali gerakan yaitu ketepatan jarak tempuh, kelurusan gerak dan berbelok dari robot, serta akurasi pembacaan halangan dengan sensor jarak guna fitur pengereman otomatis. Tujuan lain dari penelitian ini adalah guna menghitung waktu yang dibutuhkan guna melakukan sterilisasi ruangan, agar pengguna dapat menentukan waktu mulai sterilisasi sehingga dapat selesai sebelum memasuki waktu ibadah.

\section{LANDASAN TEORI}

\subsection{Prinsip Kerja Robot}

Robot sterilisasi ruangan adalah salah satu robot yang pada prinsip kerjanya bergerak untuk melewati seluruh ruangan hingga tidak ada satupun area yang terlewat dan menyinari ruangan menggunakan sinar UVC pada keseluruhan sensornya tersebut dirubah menjadi suatu nilai-nilai yang merepresentasikan rangkaian logika biner. Rangkaian logika biner ini nantinya yang akan digunakan sebagai parameter dalam menentukan pergerakan dari robot

[17].

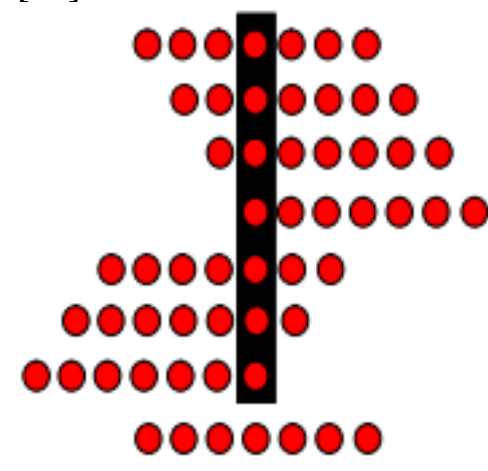

$$
\begin{aligned}
& \mathrm{Pv}=0 \\
& \mathrm{Pv}=1 \\
& \mathrm{Pv}=2 \\
& \mathrm{Pv}=3 \\
& \mathrm{Pv}=1 \\
& \mathrm{Pv}=2 \\
& \mathrm{Pv}=3 \\
& -3>\mathrm{Pv}>3
\end{aligned}
$$

Gambar 1 Logika Sensor

Dapat dilihat pada Gambar 1, disana digambarkan bagaimana pemberian nilai biner untuk logika sensor. Kemudian nilai biner tersebut diasumsikan sebagai Process Variable $(\mathrm{Pv})$ dari kondisi sensor. Nilai dari $\mathrm{Pv}$ tersebut dibuat positif dan negatif dimaksudkan agar 
nantinya mempermudah dalam perhitungan pengontrolan putaranmotor dari robot.

2.2 Mikrokontroler Arduino Uno R3

Mikrokontroler merupakan sistem pengendali utama pada robot.

Sebagai masukan dan keluaran dari sistem yang digunakan. Mikrokontroler Arduino Uno R3 ini menggunakan arsitektur RISC (Reduced

Instruction Set Computer) yang artinya prosesor tersebut memiliki set intruksi program yang lebih sedikit dibandingkan dengan MCS51 [17]. Mikrokontroler Arduino Uno R3 adalah mikrokontroler yang memiliki clock dan kinerja yang tinggi hingga $16 \mathrm{Mhz}$, memiliki 32 KB flash memori untuk menyimpan program, kapasitas SRAM sebesar 2

$\mathrm{KB}, 32$ buah port I/O untuk menghubungkan dengan LCD dan switch [17].

\subsection{Motor Driver dan Motor DC}

Driver motor merupakan salah satu perangkat yang digunakan untuk kendali motor DC. Driver motor bertugas mengendalikan arah putaran maupun kecepatan motor DC yang akan dikendalikan. Pada robot ini menggunakan driver motor BTS7960. Driver motor BTS7960 memiliki dua buah rangkaian $\mathrm{H}$-Bridge di dalamnya, sehingga dapat digunakan untuk men-drive dua buah motor DC. Pada aplikasi robotika

pergerakan robot beroda umum nya menggunakan motor DC sebagai alat penggeraknya. Motor DC merupakan motor arus

searah, perangkat elektromagnetis yang mengubah energi listrik menjadi energi mekanik menjadi tenaga gerak, sehingga tenaga gerak tersebut berupa putaran dari pada motor. Semakin besar tegangan yang diberikan maka putaran poros pada motor DC semakin cepat [18].

\subsection{Maze Solving}

Algoritma maze solving adalah algoritma yang digunakan robot untuk memecahkan lintasan yang dibuat untuk mendapatkan jalur yang tepat. Maze bisa berupa dinding atau garis. Pada penelitian ini maze yang digunakan adalah maze garis. Robot yang digunakan berjenis robot sterilisasi. Algoritma maze solving ini memiliki

dua aturan, telusur kiri (left hand rule) dan telusur kanan (right hand rule) [19]. Hal yang pertama kali dalam menjalankan algoritma ini adalah proses pemetaan (mapping) dari maze line yang ada. Pada proses pemetaan atau menghapal lintasan di setiap persimpangan yang dilewatinya robot akan memberi kode, kode tersebut disimpan dalam memori robot [19].

\section{METODE}

Alur penelitian dalam analisis sistem kendali robot Sterilisasi ruangan dengan Algoritma Maze Solving ditunjukan pada gambar 1.

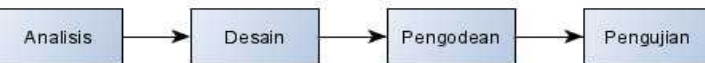

Gambar 2 Alur Penelitian

\subsection{Analisis Kebutuhan}

Pada tahapan ini dilakukan analisis kebutuhan fungsional dan non fungsional. Dilakukan

wawancara kepada 10 pengurus rumah ibadah dan tinjauan literatur guna penggunaan sinar UVC agar mendapatkan kebutuhan fungsional yang perlu diterapkan. Robot dapat meluncur dengan kecepatan konstan dan juga dapat bermanuver. Robot juga harus dapat mendeteksi halangan disekitarnya guna melakukan pengereman otomatis agar tidak menabrak. Robot sterilisasi dapat dikendalikan secara manual dengan remote dan dapat bekerja secara otomatis. Selanjutnya dilakukan analisis kebutuhan non fungsional, yang terdiri dari software dan hardware. Software yang dibutuhkan guna membuat sistem robot adalah : Arduino IDE guna pembuatan aplikasi pada Arduino dan Android Studio guna pembuatan aplikasi mobile. Hardware yang diperlukan guna membuat robot adalah Arduino Uno R3 sebagai microcontroller, dengan control panel menggunakan LCD 20x4, modul I2C, 4 push button guna navigasi dan 2 switch guna tombol power robot dan lampu UVC. Sensor yang dibutuhkan adalah 4 sensor ultrasonik HCSR04 guna mendeteksi halangan disekitar robot, 1 sensor kompas GY-BNO055 guna menjaga kelurusan gerakan, 2 sensor rotary encoder guna membaca putaran roda. Penggunaan sensor kompas GY-BNO055 lebih efektif dibandingkan dengan sensor kompas lainnya, karena tidak terpengaruh oleh medan magnet dari benda lain [14]. guna pengerak robot menggunakan 2 motor DC dengan driver motor BTS7960. guna melakukan koneksi dengan smartphone menggunakan modul bluetooth HC-06 dengan jarak hubung 15 meter tanpa penghalang dan 9 meter dengan penghalang [15]. guna daya listrik membutuhkan rechargeable battery 25.000 
$\mathrm{mAh}$, inverter $\mathrm{DC}$ to $\mathrm{AC} 220$ dihubungkan ke trafo guna menyalakan lampu UVC, relay guna menyambung dan memutus arus dan charger adaptor. guna sterilisasi menggunakan 2 lampu neon UVC 40W, dengan energi radiasi yang dipancarkan 5,6 $\mathrm{mJ} / \mathrm{cm} 2$. Energi yang dihasilkan lebih dari cukup guna menonaktifkan $99 \%$ virus Corona dengan dosis $5 \mathrm{~mJ} / \mathrm{cm} 2$ dalam waktu 6 detik [16].

2.2 Model Perancangan

Proses desain yang dilakukan pada penelitian ini terdiri dari arsitektur rancangan hardware dan flowchart software.

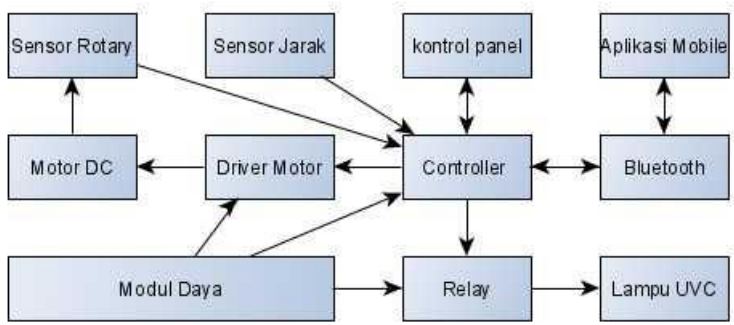

Gambar 3 Perancangan Hardware

Desain hardware pada Gambar 2 menunjukan modul sensor jarak dan sensor kompas yang

terhubung dan mengirimkan data ke controller berupa Arduino Uno. Arduino Uno adalah papan kontrol berbasis microcontroller yang digunakan sebagai pengontrol yang dapat diprogram guna mengeksekusi instruksi berdasarkan input yang diberikan ke papan [17]. Arduino Uno dapat menerima perintah dari pengguna melalui aplikasi mobile atau control panel pada robot. Arduino Uno melaksanakan fungsinya sebagai controller dengan menerima data dari sensor, mengolah data lalu mengirim perintah kedriver guna menggerakan motor dan relay guna menyambung atau memutus arus listrik dari modul daya ke lampu UVC. Putaran dari roda dibaca oleh sensor rotary encoder dan dikirim ke controller guna diolah dengan data dari sensor kompas, sehingga robot dapat mengoreksi arah gerakan dan menjaga kelurusan dengan dukungan Algoritma Maze Solving [15].

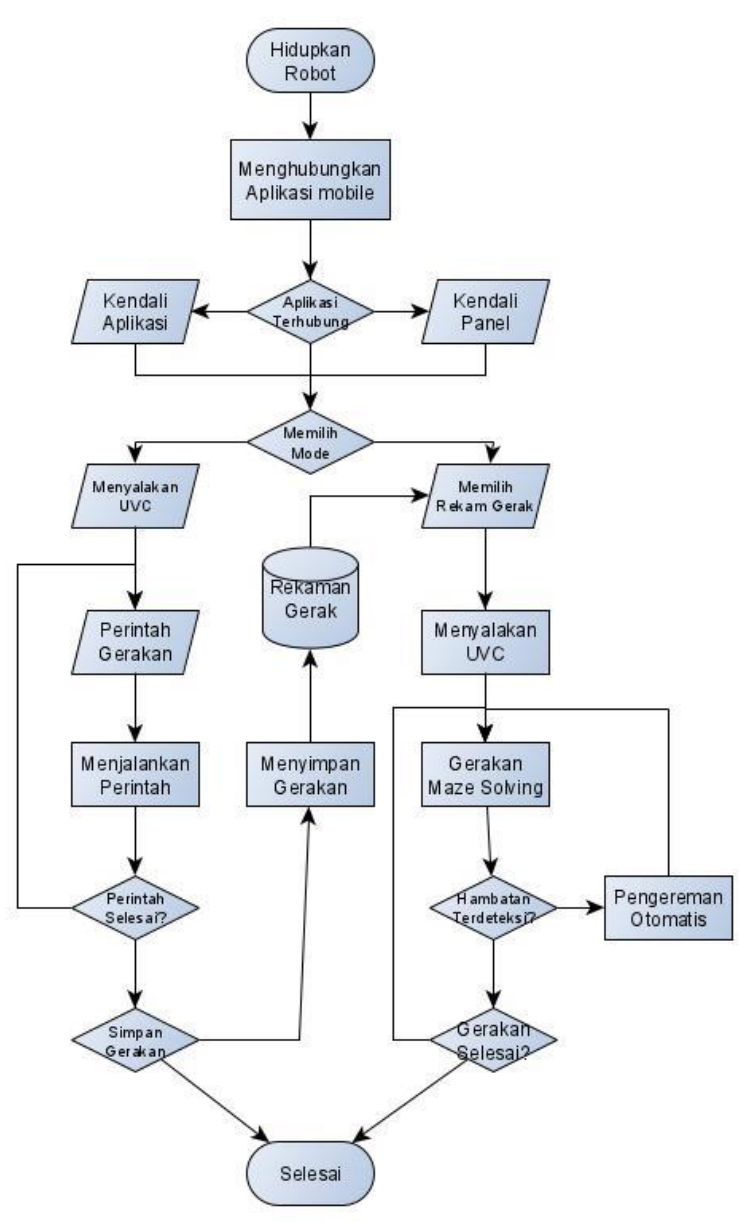

Gambar 4 Perancangan Flowchart Sistem

Gambar 4 menunjukkan alur kerja sistem robot. Perintah dapat diberikan oleh pengguna melalui control panel, pengguna dapat menjalankan dua mode perintah yaitu pengendalian otomatis dan manual. Sistem juga menerima data dari sensor rotary encoder dan sensor kompas guna diolah

menggunakan Algoritma Maze Solving dan menghasilkan perintah gerakan pada kedua motor DC, sistem akan melakukan sinkronisasi secara berulang guna menjaga laju robot tetap lurus. Jika sensor jarak mendeteksi ada penghalang pada jarak $30 \mathrm{~cm}$ di lintasan robot, maka sistem akan menjalankan perintah pengereman otomatis agar robot tidak menabrak. Sensor jarak mendeteksi jarak benda dengan cara memancarkan gelombang ultrasonik (40 KHz) selama $\mathrm{t}=200 \mathrm{us}$ kemudian mendeteksi pantulannya [14].

2.3 Penerapan Algoritma

Sistem robot sterilisasi menerapkan Algoritma Maze Solving guna meningkatkan laju gerakan, kelurusan dan berputar robot agar tidak ada bagian ruangan ibadah yang terlewatkan. Algoritma maze Solving 
merupakan salah satu algoritma yang digunakan pada robot guna mencari jalur terpendek dari sebuah line maze.Terdapat 2 aturan dalam algoritma ini, yaitu left hand rule dan right hand rule. Dalam left handrule, robot akan lebih memilih guna belok kiri dari pada lurus atau belok kanan dan jika tidak adabelokan ke kiri akan lebih memilih lurus dari pada belok kanan. Sebaliknya dalam right hand rule,robot akan lebih memilih belok kanan dari pada lurus dan lebih memilih lurus dari pada belok kiri.Dengan adanya line maze solving, robot bisa bergerak otomatis (maze) dengan berbagai cara seperti left hand rule dan right hand rule [2]. Robot yang telah diprogram dengan algoritma ini diletakkan di titik start sebuah line maze. Kemudian saat menjumpai persimpangan, robot akan memilih guna berbelok sesuai dengan prioritas dari rule yang digunakan. Hal ini terus berlanjut sambil robot menyimpan/merekam jalur yang telah dilewati ke dalam memori hingga robot menemui akhir maze (end of maze). Proses perekaman jalur ini disebut sebagai mapping. Setelah selesai, robot langsung melakukan kalkulasi/perhitungan atas jalur yang telah tersimpan dalam memori robot guna mendapatkan jalur terpendek dalam menyelesaikan maze tersebut pada penelusuran ke dua kalinya [7]. flowchart dari algoritma line maze solving dapat dilihat pada Gambar 5.

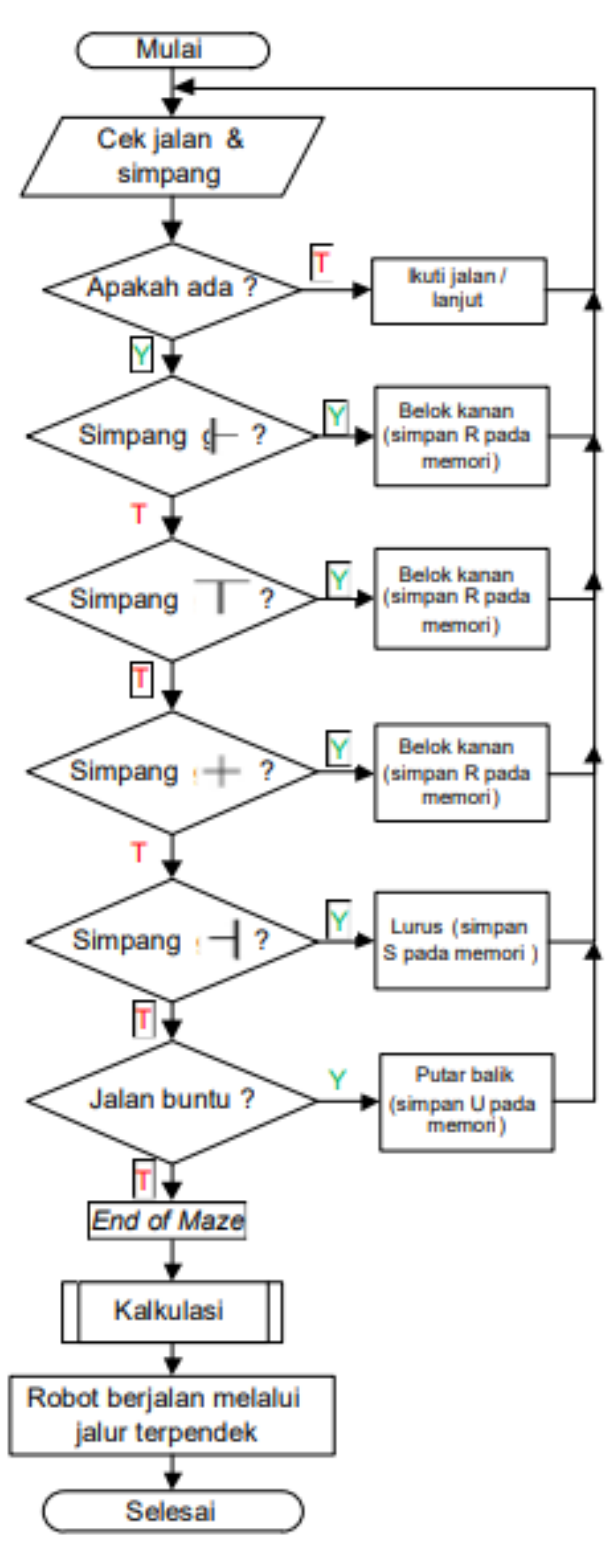

Gambar 5 Flowchart Algoritma Line Maze Solving

Terdapat 8 kemungkinan dalam maze yang ia sebut dengan "The Eight Maze Possibilities" [2].

Kedelapan kemungkinan tersebut adalah sebagai berikut:

1. tidak ada pilihan lain selain belok kiri (left turn only),

2. tidak ada pilihan lain selain belok kanan (right turn only),

3. kiri atau kanan (left or right),

4. kiri, lurus, atau kanan (four way)

5. lurus atau kiri (straight or left),

6. lurus atau kanan (straight or right),

7. jalan buntu (dead end),

8. End of maze. 


\subsection{Pengujian}

Pada tahapan ini dilakukan pengujian fungsional guna mengetahui fungsi yang dihadirkan pada aplikasi Robot Sterilisasi, dilanjutkan dengan pengujian kendali gerakan dengan dan tanpa penerapan Algoritma Maze Solving guna mengetahui dampak peningkatan kinerja robot dengan perbandingan menggunakan set-timer dan menggunakan alogritma Maze Solving.. Pengujian yang dilakukan berupa pengujian ketepatan jarak tempuh robot sterilisasi ruang ibadah, ketepatan kelurusan laju robot saat melaju dan Waktu yang dibutuhkan oleh robot untuk mensterilisasi ruangan. Penerapan Algoritma Maze Solving dalam penelitian ini menggunakan nilai $\mathrm{Kp}=$ $10, \mathrm{Ki}=0$ dan $\mathrm{Kd}=120$. Kemudian dilakukan pengujian jarak pendeteksi halangan yang optimal guna mendukung fungsi pengereman otomatis. Pada tahapan pengujian waktu dilakukan perhitungan waktu yang dibutuhkan oleh robot dalam proses sterilisasi sesuai luasan bidang ruangan. Pengolahan data dalam penelitian ini menggunakan metode standar deviasi. Standar deviasi adalah pengukuran sebaran data yang digunakan guna mengetahui homogenitas suatu kelompok data atau menentukan sebaran data dalam suatu sampel dan seberapa dekat suatu titik data dengan garis data nilai rata-rata [22]. Semakin besar nilai distribusi standar deviasi berarti variasi nilai datanya semakin besar.

\section{HASIL DAN PEMBAHASAN}

\subsection{Tampilan Hardware}

Robot yang digunakan sebagai hardware memiliki ukuran badan $60 \mathrm{~cm}$ dengan lebar $25 \mathrm{~cm}$ dan tinggi $30 \mathrm{~cm}$. Robot menggunakan 2 roda penggerak pada bagian depan dan roda bebas pada bagian belakang yang berfungsi untuk mempermudah berbelok.

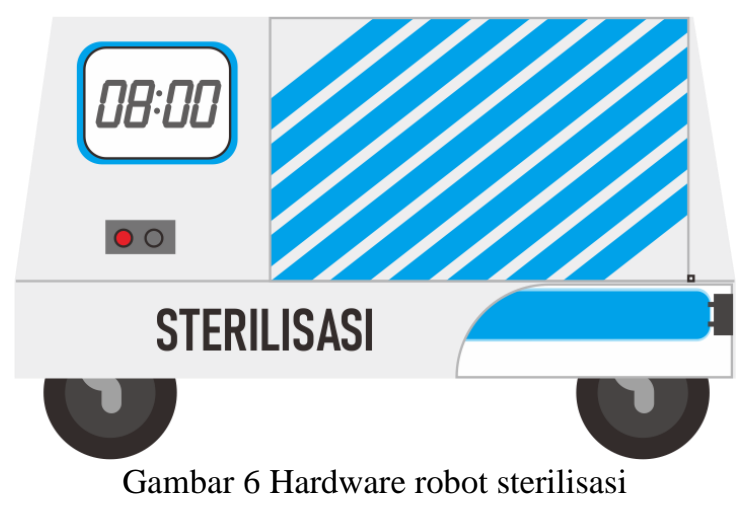

Gambar 6 menunjukkan tampilan hardware dari robot dengan rangka alumunium. Lampu UVC ditempatkan di bagian dalam robot sebelah bawah Lampu UVC ditutup oleh reflektor pada bagian atas dan samping yang berfungsi memantulkan sinar UVC sehingga hanya mengarah ke bawah dan tidak terpapar pada orang disekitar. Control panel diletakan di bagian atas dan sensor jarak diletakan sejumlah 1 buah di depan , 1 buah di belakang dan 1 buah di bahian kanan dan kiri. Untuk peralatan elektronik lainnya dan modul daya diletakan di dalam badan robot.

\subsection{Pengujian Gerak}

Pengujian kendali gerak dilakukan dengan cara variasi masing masing jarak dilakukan

pengujian sebanyak 3 kali membandingkan menggunakan set-timer dengan menggunakan Algoritma Maze Solving beserta sensor rotary encoder dan sensor kompas. Hasil pengujian di tunjukan pada table 1 .

Tabel 1. Hasil Pengujian Jarak Tempuh

\begin{tabular}{lllll}
\hline No & \multicolumn{3}{c}{ Hasil Gerak } \\
\cline { 2 - 5 } & $\begin{array}{c}\text { Jarak } \\
(\mathbf{c m})\end{array}$ & Teknik & $\begin{array}{c}\text { Rata } \\
\text { Rata }\end{array}$ & $\begin{array}{c}\text { Standar } \\
\mathbf{t} \\
\text { Deviasi }\end{array}$ \\
\hline 1 & 100 & Set-Timer & 98.71 & 4.54 \\
\hline 2 & 200 & Set-Timer & 211.41 & 5.65 \\
\hline 3 & 500 & Set-Timer & 512.31 & 7.31 \\
\hline 4 & 1000 & Set-Timer & 1015.8 & 10.4 \\
\hline 5 & 100 & Maza Solving & 100.21 & 0.15 \\
\hline 6 & 200 & Maza Solving & 203.14 & 0.20 \\
\hline 7 & 500 & Maza Solving & 502.3 & 0.30 \\
\hline 8 & 1000 & Maza Solving & 1003.2 & 0.42 \\
\hline
\end{tabular}

Dapat diketahui dari table 1, jarak tempuh robot yang semakin jauh maka kesalahan yang terjadi juga semakin besar, ditunjukan dengan selisih antara rata-rata jarak tempuh sebenarnya dengan yang direncanakan. Nilai standar deviasi juga semakin meningkat pada jarak tempuh yang semakin jauh, menggambarkan sebaran hasil yang semakin bervariasi. Tetapi penggunaan Algoritma Maze Solving menunjukan hasil kesalahan jarak tempuh yang

lebih kecil dibandingkan hanya menggunakan teknik set-timer. Algoritma Maze Solving berfungsi untuk mengoreksi posisi robot berdasarkan besar error yang didapat, sehingga robot dapat mengoreksi kesalahan posisi robot untuk semakin dekat ke set point [18]. Algoritma Maze Solving dapat mengendalikan gerakan robot lebih tepat, dengan selisih kesalahan terbesar hanya $3,2 \mathrm{~cm}$ dengan standar deviasi terbesar 0,42 pada jarak tempuh $1.000 \mathrm{~cm}$. Sedangkan teknik set-timer menunjukan selisih kesalahan terbesar 
mencapai $15.8 \mathrm{~cm}$ dengan standar deviasi terbesar 10.4 pada jarak

tempuh $1.000 \mathrm{~cm}$.

Pengujuan Berbelok dilakukan dengan mengetes pergerakan robot menggunakan algoritma Maze Solving dan hasilnya dapat di lihat pada tabel 2.

Tabel 2. Hasil Pengujian Gerakan Lurus

\begin{tabular}{llccc}
\hline No & \multicolumn{4}{c}{ Percobaan ke } \\
\cline { 2 - 5 } & $\begin{array}{l}\text { Gerakan } \\
\text { Robot }\end{array}$ & $\mathbf{1}$ & $\mathbf{2}$ & $\mathbf{3}$ \\
\hline 1 & Lurus & Berhasil & Berhasil & Berhasil \\
\hline 2 & $\begin{array}{l}\text { Belok } \\
\text { Kanan }\end{array}$ & Berhasil & Berhasil & Berhasil \\
\hline 3 & Belok Kiri & Berhasil & Berhasil & Berhasil \\
\hline 4 & $\begin{array}{l}\text { Berbalik } \\
\text { arah }\end{array}$ & Berhasil & Berhasil & Berhasil \\
\hline
\end{tabular}

Dari tabel ke 2 dapat kita ketahui bahwa pengujian gerak robot dilakukan dalam 3 kali percobaan.

Pengujian kelurusan dilakukan dengan menghitung selisih jarak posisi hasil akhir gerakan robot dengan garis lurus ditarik dari titik awal gerakan. Pengujian dilakukan sebanyak 3 kali dengan 5 variasi jarak tempuh yang membandingkan gerakan robot dengan dan tanpa penerapan Algoritma Maze Solving. Hasil pengujian ditunjukan pada Tabel 3.

Tabel 3. Hasil Pengujian Gerakan Lurus

\begin{tabular}{lllll}
\hline No & \multicolumn{3}{c}{ Hasil Gerak lurus } \\
\cline { 2 - 5 } & $\begin{array}{c}\text { Jarak } \\
(\mathbf{c m})\end{array}$ & Teknik & $\begin{array}{c}\text { Rata } \\
\text { Rata }\end{array}$ & $\begin{array}{c}\text { Standar } \\
\mathbf{t} \\
\text { Deviasi }\end{array}$ \\
\hline 1 & 100 & Set-Timer & 4.5 & 1.32 \\
\hline 2 & 200 & Set-Timer & 5.3 & 2.24 \\
\hline 3 & 500 & Set-Timer & 10.5 & 4.50 \\
\hline 4 & 1000 & Set-Timer & 32.5 & 10.21 \\
\hline 5 & 100 & Maza Solving & 0.4 & 0.23 \\
\hline 6 & 200 & Maza Solving & 1.1 & 0.25 \\
\hline 7 & 500 & Maza Solving & 1.3 & 0.33 \\
\hline 8 & 1000 & Maza Solving & 1.8 & 0.35 \\
\hline
\end{tabular}

Dari Tabel 3 diketahui bahwa gerakan robot dengan set-timer menujukan semakin jauh jarak

yang ditempuh robot semakin melenceng dari garis lurus atau set point. Selisih posisi dari garis lurus terbesar mencapai $32.5 \mathrm{~cm}$, dengan standar deviasi tertinggi mencapai 10.21. Penerapan Algoritma Maze Solving menujukan hasil pergerakan robot yang stabil pada jarak tempuh jauh maupun dekat, dengan selisih posisi dari garis lurus terbesar hanya $1.8 \mathrm{~cm}$ dengan standar deviasi terbesar 0,35.

\subsection{Penghitungan Waktu Sterilisasi}

Perhitungan waktu sterilisasi dilakukan untuk mengetahui waktu yang dibutuhkan robot untuk proses sterilisasi luasan tertentu dari bidang lantai ruangan agar pengguna dapat menjadwalkan waktu mulai sterilisasi, sehingga proses sterilisasi dapat selesai tepat waktu.

Perhitungannya adalah sebagai berikut:

Kecepatan gerak lurus $=\quad 4 \mathrm{~cm} /$ detik

$2 \mathrm{~m} /$ menit

Waktu berbelok $180^{\circ}=1 / 3$ menit $/$ belok

Robot mempunyai lebar $60 \mathrm{~cm}$ dan setiap bergerak robot menyapu luasan $60 \mathrm{~cm}$.

Waktu untuk gerak lurus = panjang lantai $/$ kecepatan gerak lurus $\mathrm{x}$ lebar lantai

Waktu untuk berbelok $=$ jumlah belokan $\mathrm{x}$ waktu untuk berbelok

Waktu sterilisasi $=$ Jumlah waktu untuk gerak lurus + Jumlah waktu untuk berbelok Dari data di atas didapat rumus seperti ditunjukan pada Persamaan 1.

$$
\mathrm{WS}=((\mathrm{PL} x \mathrm{LL})+(\mathrm{LL}-1)) / 3 \ldots \ldots(1)
$$

Keterangan :

WS = Waktu Sterilisasi

PL = Panjang Lantai

LL = Lebar Lantai

Dimana (Waktu Sterilisasi) adalah waktu yang dibutuhkan untuk melakukan proses sterilisasi. (panjang lantai) adalah jarak dinding kiri dan kanan ruangan dan (lebar lantai) adalah jarak dinding depan dan belakang masjid. Untuk jumlah belokan yang terjadi adalah sejumlah lebar lantai dalam meter dikurangi 1 (lebar lantai - 1). Penjumlahan dari keduanya dibagi 3 yaitu kecepatan gerak robot 3 meter / menit.

Untuk sterilisasi bidang lantai ruangan dengan ukuran $10 \times 10$ meter, dibutuhkan waktu sebagai berikut:

Waktu Sterilisasi $=((10 \times 10)+(10-1)) / 2$ $=54,5$ menit

Dari perhitungan di atas dapat diketahui waktu yang dibutuhkan untuk melakukan proses sterilisasi lantai ruangan berukuran $10 \mathrm{~m}$ x $10 \mathrm{~m}$ menggunakan robot sterilisasi selama 36,3 menit.

\section{KESIMPULAN}

Dari hasil pengujian dan analisa didapat kesimpulan bahwa semua fungsi robot sterilisasi dapat berjalan dengan baik. Penerapan Algoritma Maze Solving dengan 
nilai $\mathrm{Kp}=10, \quad \mathrm{Ki}=0 \quad$ dan $\quad \mathrm{Kd}=120 \quad$ yang dikombinasikan dengan sensor kompas, sensor rotary encoder dan sensor jarak terbukti dapat meningkatkan kinerja sistem kendali robot Sterilisasi ruangan dibandingkan dengan penggunaan teknik set-timer. Hasil pengujian menunjukkan peningkatan kinerja kendali robot dengan nilai standar deviasi tertinggi untuk ketepatan jarak tempuh menurun dari 10.46 menjadi 0,44 dan nilai standar deviasi tertinggi untuk kelurusan gerak menurun dari 10.21 menjadi 0,35 . Proses sterilisasi ruangan dengan ukuran 10 m x 10 m membutuhkan waktu 36,3 menit. Penelitian ini dapat menjadi pilot project penelitian lainnya, terutama pengembangan ke arah penerapan mode autonomous system pada robot sterilisasi lantai.

\section{DAFTAR PUSTAKA}

[1] Yuliana, "Corona virus diseases (Covid -19); Sebuah tinjauan literatur," WELLNESS Heal. Mag.,

vol. 2, no. February, pp. 187 - 192, 2020.

[2] A. D. Elisanti, E. T. Ardianto, N. C. Ida, and E. Hendriatno, "Effectiveness Of Uv And Alcohol 70\% Exposure To Total Bacteria Of Folding Money Circulating During The Pandemic Covid-19,"

[3] F. A. Juarez-Leon, A. G. SorianoSanchez, M. A. Rodriguez-Licea, and F. J. Perez-Pinal, "Design and implementation of a germicidal UVCLED lamp," IEEE Access, vol. 8, pp. 11, 2020, doi.

[4] N. Storm et al., "Rapid and complete inactivation of SARS-CoV-2 by ultraviolet-C irradiation," pp. 1-7, 2020, [Online]. Available: https://doi.org/10.21203/rs.3.rs65742/v1S.

[5] M. Lamatenggo, I. Wiranto, and W. Ridwan, "Perancangan Balancing Robot Beroda Dua Dengan Metode Pengendali PID Berbasis Arduino Nano," Jambura J. Electr. Electron. Eng., vol. 2, no. 2, pp. 39-43,2020,doi: 10.37905/jjeee.v2i2.6906.

[6] F. Zuhri Ramdhani, D. Riyanto Riyanto, and D. Desriyanti, "Electronic Sterilization of Tableware Using Ultraviolet Light Radiation," JEEE-U (Journal Electr. Electron. Eng.
UMSIDA), vol. 4, no. 1, pp. 70-79, 2020, doi: 10.21070/jeeeu.v4i1.316.

[7] A. Fikri, "Kemiripan Arsitektur Tiang Masjid Ampel Karangasem Bali dengan Masjid Agung Demak," in Seminar Ikatan Peneliti Lingkungan Binaan Indonesia (IPLBI) 1, 2017, pp. A351A354, doi: 10.32315/sem.1.a351.

[8] N. Sudin, I. Djufri, and M. Umar, "Rancang Bangun Sistem Pengontrol Lampu Rumah Berbasis Mikrokontroler Arduino Uno Menggunakan Smartphone," J. Ilm. Ilk. - Ilmu Komput. Inform., vol. 3, Jul. 2020, doi: 10.47324/ilkominfo.v3i2.102.G.

[9] S. S. Dheeban, D. V. Harish, A. Hari Vignesh, and M. Prasanna, "Arduino Controlled Gesture Robot," 2018 IEEE 4th Int. Symp. Robot. Manuf. Autom. ROMA 2018, pp. 1-6, 2018, doi: 10.1109/ROMA46407.2018.8986730.

[10] A. Mappa and M. D. T. Sogen, "Rancang Bangun Prototype Sistem Pengendalian Kecepatan Dan Pengereman Menggunakan Sensor Jarak," Electro Luceat, vol. 5, no. 2, pp. 48-61, 2019, doi: 10.32531/jelekn.v5i2.153

[11] D. Diana and J. Al-Rasyid, "Implementasi Sensor Compas HMC5883L Terhadap Gerak Robot Micromouse dengan Menggunakan Algoritma PID," J. Tek. Elektro ITP, vol. 6 , no. 2, pp. 120-124, 2017, doi: 10.21063/jte.2017.3133616.

[12] Iswanto. (2008). Design dan Implementasi Sistem Embedded Mikrokontroler ATMega8535 dengan Bahasa Basic. Yogyakarta: Penerbit Gava Media.

[13] Anshori, Y., Dodu, A. E., \& Kurniawan, F. (2019). Perancangan Robot Penelusur Menggunakan Algoritma Dijkstra dan Metode Maze Solving. Techno. Com, 18(2), 166-177.

[14] Prayudha, J., Saripurna, D., \& Nugroho, N. B. (2017). Implementasi Backpropagation Untuk Pengenalan Warna Garis Lintasan Robot Maze Solving Berbasis Arduino. Jurnal SAINTIKOM, 16(2). Proc. Natl. Acad. Sci. India Sect. A - Phys. Sci., vol. 89, no. 2, hal. 291-309, Jun 2019.

[15] Saar, M., Gilad, T., Kilon-Kallner, T., Rosenfeld, A., Subach, A. \& Scharf, I. 
(2017). The interplay between maze complexity, colony size, learning and memory in ants while solving a maze: a test at the colony level. - PLoS One 12: e0183753

[16] A. Mappa and M. D. T. Sogen, "Rancang Bangun Prototype Sistem Pengendalian Kecepatan Dan

Pengereman Menggunakan Sensor Jarak," Electro Luceat, vol. 5, no. 2, pp. 48-61, 2019, 10.32531/jelekn.v5i2.153.
[17] Prabowo, Y. 2013. "Aplikasi PID pada Robot Line Follower Bebasis Mikrokontroler AT-8535". Arsitron, Vol. 4 No.1 Juni 2018

[18] Bishop, O. (2018). Dasar-Dasar Elektronika. Jakarta: Penerbit Erlangga.

[19] Yultrisna dan Andi Sofyan (2013) "Rancang Bangun Robot Solving Maze Dengan Algoritma Depth First Search". MOMENTUM, Vol.15,No.2, ISSN : 1693-752X. 